\title{
New syntheses of 5,6- and 7,8-diaminoquinolines
}

\author{
Maroš Bella ${ }^{* 1}$ and Viktor Milata ${ }^{2}$
}

\author{
Full Research Paper \\ Address: \\ ${ }^{1}$ Institute of Chemistry, Slovak Academy of Sciences, Dúbravská \\ cesta 9, SK-845 38 Bratislava, Slovakia and ${ }^{2}$ Department of Organic \\ Chemistry, Faculty of Chemical and Food Technology, Slovak \\ University of Technology, Radlinského 9, SK-812 37 Bratislava, \\ Slovakia \\ Email: \\ Maroš Bella* - maros.bella@savba.sk \\ * Corresponding author \\ Keywords: \\ chlorination; deselenation; nitrogen heterocycles; \\ o-diaminoquinolines; selenadiazoloquinolones
}

\begin{abstract}
Beilstein J. Org. Chem. 2013, 9, 2669-2674.
doi:10.3762/bjoc.9.302
\end{abstract}

Received: 24 June 2013

Accepted: 04 November 2013

Published: 27 November 2013

Associate Editor: T. J. J. Müller

(c) 2013 Bella and Milata; licensee Beilstein-Institut. License and terms: see end of document.

\begin{abstract}
The synthesis of 5,6- and 7,8-diaminoquinoline derivatives starting from angularly annelated selenadiazoloquinolones is presented. Simple chlorination of the pyridone ring followed by reductive deselenation of the 1,2,5-selenadiazole ring afforded novel 4-chloro$o$-diaminoquinolines. Dechlorination of 4-chloro-7,8-diaminoquinoline gave 7,8-diaminoquinoline hydrochloride which was successfully employed as starting material in the synthesis of condensed nitrogen heterocycles.
\end{abstract}

\section{Introduction}

$o$-Diaminoquinolines, in particular 5,6- and 7,8-diaminoquinolines, represent valuable intermediates in the synthesis of nitrogen-containing heterocycles [1-3] including food-borne carcinogens [4].

To date, the known procedures for the synthesis of 7,8-diaminoquinoline have started from 3-nitroaniline or 3-chloroaniline. Initially, 7,8-diaminoquinoline was prepared by Renshaw et al. [5] by coupling 7-aminoquinoline with benzenediazonium chloride followed by the reduction of the resulting azo-dye with $\mathrm{SnCl}_{2} \cdot 2 \mathrm{H}_{2} \mathrm{O}$. The second method relies on the Skraup reaction [6] of 3-nitroaniline affording 7-nitroquinoline in a low yield $(14 \%)$. The latter was reduced with iron in acetic acid to 7-aminoquinoline which was subsequently tosylated, nitrated in position 8 and detosylated to yield 7-amino-8-nitroquinoline. In the final step, the reduction of aminonitroquinoline with $\mathrm{SnCl}_{2} \cdot 2 \mathrm{H}_{2} \mathrm{O}$ provided 7,8-diaminoquinoline [7]. Another approach is based on the amination of 7-nitroquinoline in position 8 with hydroxylamine under basic conditions. The resulting 8-amino-7-nitroquinoline was reduced with $\mathrm{SnCl}_{2} \cdot 2 \mathrm{H}_{2} \mathrm{O}$ [8] or hydrazine hydrate on Raney nickel as a catalyst [9] to obtain 7,8-diaminoquinoline. In the last method, the Skraup reaction of 3-chloroaniline led to 7-chloroquinoline which, after nitration, replacement of the chlorine atom by the amino group and catalytic hydrogenation on $5 \%$ palladium on charcoal, yielded 7,8-diaminoquinoline [10]. 
The preparation of 5,6-diaminoquinoline is more effective because the Skraup reaction of 4-nitroaniline produces 6-nitroquinoline as a sole product in moderate yield (47\%). The latter, on treatment with hydroxylamine hydrochloride in the presence of $\mathrm{KOH}$ [11] followed by the reduction with hydrazine hydrate on Raney nickel, provided 5,6-diaminoquinoline in almost quantitative yield [12].

A disadvantage of the syntheses of $o$-diaminoquinolines described above is that they require the Skraup reaction, which usually gives low yields and can be violently exothermic [6] Moreover, in the case of 3-nitro- and 3-chloroaniline, the Skraup reaction affords a mixture of 5- and 7-substituted quinolines, making their separation necessary. To avoid these drawbacks, the readily available angularly annelated selenadiazoloquinolones, prepared as detailed in our previous papers [13,14], were employed as the precursors of $o$-diaminoquinoline derivatives. The preparation and application of 7,8-diaminoquinoline hydrochloride in the synthesis of nitrogen heterocycles is discussed in datail.

\section{Results and Discussion}

In the present approach, selenadiazoloquinolones 1 and $\mathbf{9}$ represent a masked form of the target $o$-diaminoquinolines where the $o$-phenylenediamine moiety is protected as the 2,1,3-benzoselenadiazole skeleton while the pyridine ring can be obtained by transformation of the pyridone core [15]. The synthesis of 7,8diaminoquinoline (3) starting from selenadiazolo[3,4$h$ ]quinolone 1 is depicted in Scheme 1. In the first step, the aromatization of the pyridone ring by chlorination with $\mathrm{POCl}_{3}$ in DMF, which worked reliably on related azoloquinolones [15], was attempted. However, in the case of selenadiazolo[3,4$h$ ]quinolone $\mathbf{1}$, only decomposition products were observed. On the other hand, chlorination with neat $\mathrm{POCl}_{3}$ at $90{ }^{\circ} \mathrm{C}$ afforded 6-chloroselenadiazoloquinoline 2 in 74\% yield after recrystallisation from toluene (Scheme 1). The temperature of the chlorination $\left(90^{\circ} \mathrm{C}\right)$ was found to be crucial, since heating of the reaction mixture under reflux led to a rapid decomposition. The catalytic hydrogenation of 6-chloroderivative 2 using $10 \%$ palladium on charcoal or Raney nickel did not afford 7,8diaminoquinoline (3) in a single step. Finally, the simultaneous deselenation and dechlorination of 6-chloroderivative 2 with zinc in refluxing acetic acid accessed 7,8-diaminoquinoline (3) in $31 \%$ yield. Due to the low yield of diaminoquinoline 3 following the treatment with zinc in acetic acid, the reduction of 6-chloroderivative 2 was performed in two successive steps. First, the reductive deselenation with $\mathrm{SnCl}_{2} \cdot 2 \mathrm{H}_{2} \mathrm{O}$ in concentrated hydrochloric acid afforded 4-chlorodiaminoquinoline $\mathbf{4}$ in $89 \%$ yield. The subsequent catalytic hydrogenation on $10 \%$ palladium on charcoal in the absence of base, after filtration of the catalyst and evaporation of methanol, gave 7,8-diaminoquinoline hydrochloride (5) in high yield (Scheme 1). It was notable that the use of sodium hydroxide as a base during the catalytic hydrogenation either on $10 \%$ palladium on charcoal or Raney nickel did not lead to diaminoquinoline 3. After alkalisation of the hydrochloride $\mathbf{5}$ with a sodium hydroxide solution, diaminoquinoline 3 was isolated in good yield (61\%). However, 7,8-diaminoquinoline (3) is relatively unstable and decomposes slowly both during isolation or subsequent to it. Hence, the isolation of free diaminoquinoline $\mathbf{3}$ is practically irreproducible due to this instability. Accordingly, it is far more convenient to employ hydrochloride $\mathbf{5}$ as the starting material in the subsequent reactions, whether isolated or prepared in situ.

Next, hydrochloride $\mathbf{5}$ was applied as the substrate in the synthesis of nitrogen heterocycles (Scheme 2). The treatment of

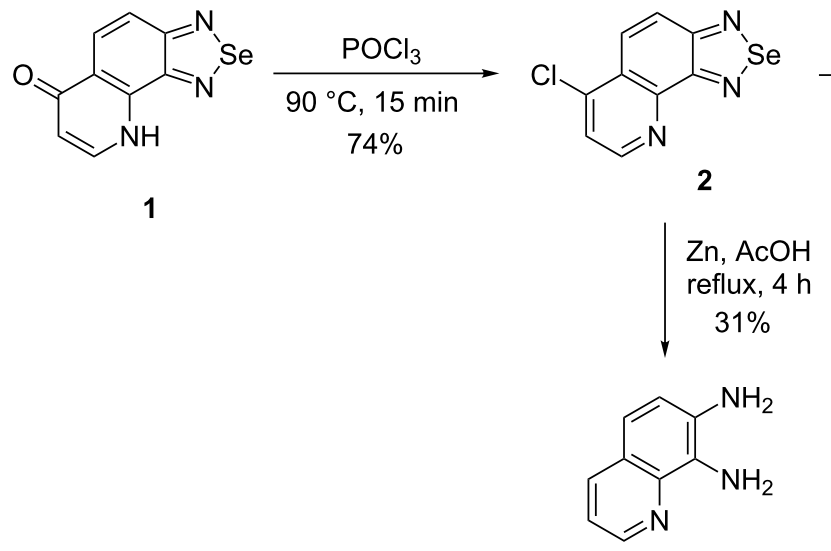

3

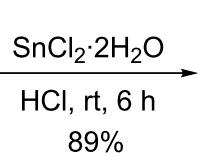

$89 \%$<smiles>Nc1ccc2c(Cl)ccnc2c1N</smiles>

\section{4}

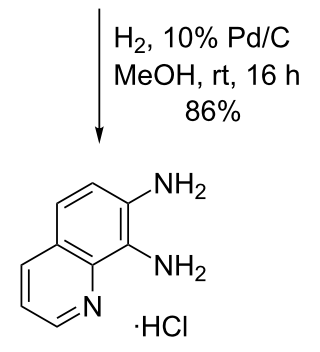

5 


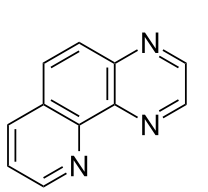

8

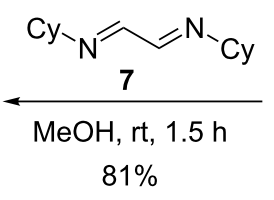

$\underbrace{N_{2}}_{-\mathrm{NCl}}$

5

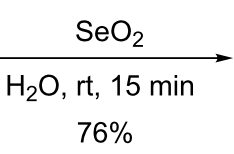

$\underbrace{S}_{=N}$

6

Scheme 2: Application of hydrochloride 5 in the syntheses of nitrogen heterocycles

hydrochloride $\mathbf{5}$ with selenium dioxide in water at room temperature afforded selenadiazoloquinoline $\mathbf{6}$ in $76 \%$ yield (Scheme 2) in comparison with $18 \%$ yield obtained by heating of diaminoquinoline 3 with selenium dioxide in dioxane under reflux [9]. To date, pyridoquinoxaline 8 has been prepared in a poor yield by application of the Skraup synthesis to 5-acetylamidoquinoxaline [16]. Notably, 7,8-diaminoquinoline dihydrochloride condensed with glyoxal bisulfite only with the amino group in position 7 and the pyrazine ring was not closed [17]. In the present case, the cyclocondensation of hydrochloride 5 with diimine 7 [18,19] proceeded smoothly at room temperature affording pyridoquinoxaline $\mathbf{8}$ in high yield (Scheme 2).

The same reaction sequence (chlorination and reductive deselenation) was applied to selenadiazolo[3,4-f]quinolone 9 (Scheme 3). The treatment of selenadiazoloquinolone 9 with $\mathrm{POCl}_{3}$ led to 9-chloroselenadiazoloquinoline $\mathbf{1 0}$ in high yield. Unlike the reduction of 6-chloroderivative 2, the reductive deselenation of 9-chloroderivative $\mathbf{1 0}$ proceeded much more rapidly and 4-chloro-5,6-diaminoquinoline (11) was isolated in 77\% yield. However, it should be noted that this reductive deselenation required careful monitoring by TLC $\left(\mathrm{CHCl}_{3} / \mathrm{MeOH} 100: 1\right.$, $\left.R_{\mathrm{f}}=0.10\right)$ at $10 \mathrm{~min}$ intervals in order to detect its accurate termination, because prolongation of the reaction time results in decreased yields.

\section{Conclusion}

Angularly annelated selenadiazoloquinolone $\mathbf{1}$ and $\mathbf{9}$ were successfully employed as starting materials in the synthesis of 5,6- and 7,8-diaminoquinoline derivatives. 7,8-Diaminoquinoline hydrochloride (5) was prepared in three steps in $57 \%$ overall yield starting from selenadiazolo[3,4-h]quinolone $\mathbf{1}$. Hydrochloride $\mathbf{5}$ was applied as an important intermediate in the synthesis of nitrogen heterocycles. Hydrochloride $\mathbf{5}$ affords the advantages of stability in air and simple isolation; it could also be used in further reactions prepared in situ without isolation. In addition, 4-chloro-o-diaminoquinolines $\mathbf{4}$ and $\mathbf{1 1}$ also represent valuable substrates for the preparation of chlorinated nitrogen heterocycles.

\section{Experimental}

General. Thin-layer chromatography (TLC) was performed on aluminium plates precoated with $0.2 \mathrm{~mm}$ silica gel $(25 \mu \mathrm{m})$ containing fluorescent indicator $254 \mathrm{~nm}$ (Fluka) and stains were visualised by UV light ( $254 \mathrm{~nm}$ or $366 \mathrm{~nm}$ ). Flash liquid chromatography (FLC) was performed on silica gel [Normasil 60 $(43-60 \mu \mathrm{m})]$. Melting points were measured on a Koffler block and are uncorrected. ${ }^{1} \mathrm{H}$ NMR and ${ }^{13} \mathrm{C}$ NMR spectra were recorded on a Varian Mercury $300 \mathrm{MHz}$ spectrometer at $25^{\circ} \mathrm{C}$. The operating frequencies were $300 \mathrm{MHz}$ for ${ }^{1} \mathrm{H}$ and $75.5 \mathrm{MHz}$ for ${ }^{13} \mathrm{C}$ nuclei. Chemical shifts $(\delta)$ are reported in ppm and coupling constants $(J)$ are given in Hz. Elemental analyses were determined using a Thermo Finnigan Flash EA 1112 instrument.

6-Chloro-[1,2,5]selenadiazolo[3,4-h]quinoline (2). A mixture of selenadiazolo[3,4- $h$ ]quinolone $1(5.0 \mathrm{~g}, 20.0 \mathrm{mmol})$ and $\mathrm{POCl}_{3}(10 \mathrm{~mL}, 16.4 \mathrm{~g}, 0.1 \mathrm{~mol})$ was stirred at $90{ }^{\circ} \mathrm{C}$ for $15 \mathrm{~min}$. After the reaction was complete, the mixture was cooled to $0{ }^{\circ} \mathrm{C}$ in an ice bath followed by the addition of crushed ice $(\sim 45 \mathrm{~g})$ in one portion under stirring. Once the ice was melted, the resulting brown solution was alkalised with a $20 \% \mathrm{NaOH}$ solution under cooling in the ice bath. The brown precipitate was<smiles>O=c1cc[nH]c2ccc3n[se]nc3c12</smiles>

9<smiles>Clc1ccnc2ccc3n[se]nc3c12</smiles>

10

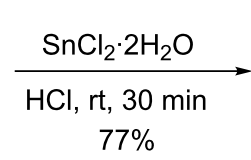

$77 \%$<smiles>Nc1ccc2nccc(Cl)c2c1N</smiles>

11

Scheme 3: Synthesis of 4-chloro-5,6-diaminoquinoline (11). 
collected by suction, washed with acetone and dried. Recrystallisation from toluene gave 6-chloroselenadiazoloquinoline 2 (4.0 g, 74\%) as golden plates; $\mathrm{mp} 237-240{ }^{\circ} \mathrm{C} ;{ }^{1} \mathrm{H}$ NMR (300 MHz, TFA- $d$ ) $\delta 8.08$ (d, $J=9.8 \mathrm{~Hz}, 1 \mathrm{H}, \mathrm{H}-4), 8.17$ (d, $J=6.0$ $\mathrm{Hz}, 1 \mathrm{H}, \mathrm{H}-7), 8.30$ (d, $J=9.8 \mathrm{~Hz}, 1 \mathrm{H}, \mathrm{H}-5), 8.86$ (d, $J=6.0 \mathrm{~Hz}$, $1 \mathrm{H}, \mathrm{H}-8) ;{ }^{13} \mathrm{C}$ NMR $(75 \mathrm{MHz}, \mathrm{TFA}-d) \delta 127.1,128.5,128.8$, $131.1,136.8,143.6,151.9,158.5,161.4$; anal. calcd for $\mathrm{C}_{9} \mathrm{H}_{4} \mathrm{ClN}_{3} \mathrm{Se}: \mathrm{C}, 40.25 ; \mathrm{H}, 1.50$; N, 15.65; found: $\mathrm{C}, 40.19$; $\mathrm{H}$, $1.48 ; \mathrm{N}, 15.70$.

4-Chloro-7,8-diaminoquinoline (4). $\mathrm{SnCl}_{2} \cdot 2 \mathrm{H}_{2} \mathrm{O}$ (4.0 g, $17.7 \mathrm{mmol}$ ) was added in small portions to a stirred suspension of 6-chloroselenadiazoloquinoline $2(1.0 \mathrm{~g}, 3.7 \mathrm{mmol})$ in concentrated $\mathrm{HCl}(33 \mathrm{~mL})$ at room temperature and stirring was continued for $6 \mathrm{~h}$. Next, the reaction mixture was diluted with water $(30 \mathrm{~mL})$, the insoluble material was removed by filtration under reduced pressure and the filter cake was washed thoroughly with water $(150-200 \mathrm{~mL})$. The filtrate was subsequently alkalised with a $20 \% \mathrm{NaOH}$ solution under cooling in an ice bath and the resulting yellow suspension was extracted with ethyl acetate $(3 \times 100 \mathrm{~mL})$. The combined organic phases were dried with $\mathrm{Na}_{2} \mathrm{SO}_{4}$, filtered and the solvent evaporated under reduced pressure to afford 4-chlorodiaminoquinoline $\mathbf{4}$ $(0.64 \mathrm{~g}, 89 \%)$ as a yellow solid which was used in the next reaction without further purification; mp $136-139{ }^{\circ} \mathrm{C} .{ }^{1} \mathrm{H}$ NMR (300 MHz, DMSO-d $\left.)_{6}\right) \delta .19$ (br s, 2H, NH ), 5.25 (br s, $2 \mathrm{H}$, $\left.\mathrm{NH}_{2}\right), 7.14$ (d, $\left.J=8.7 \mathrm{~Hz}, 1 \mathrm{H}, \mathrm{H}-6\right), 7.28(\mathrm{~d}, J=8.7 \mathrm{~Hz}, 1 \mathrm{H}$, H-5), 7.29 (d, $J=4.6 \mathrm{~Hz}, 1 \mathrm{H}, \mathrm{H}-3), 8.50$ (d, $J=4.6,1 \mathrm{H}, \mathrm{H}-2$ ); ${ }^{13} \mathrm{C}$ NMR $\left(75 \mathrm{MHz}, \mathrm{DMSO}-d_{6}\right) \delta 110.9,116.7,118.5,119.4$, 127.0, 133.7, 138.3 140.7, 146.8; anal. calcd for $\mathrm{C}_{9} \mathrm{H}_{8} \mathrm{ClN}_{3}: \mathrm{C}$, 55.83; H, 4.16; N, 21.70; found: C, 55.92; H, 4.20; N, 21.61.

7,8-Diaminoquinoline hydrochloride (5). $10 \% \mathrm{Pd} / \mathrm{C}(0.40 \mathrm{~g})$ was added to a solution of 4-chlorodiaminoquinoline 4 ( $0.64 \mathrm{~g}$, $3.3 \mathrm{mmol})$ in methanol $(35 \mathrm{~mL})$ and the resulting mixture was stirred under $\mathrm{H}_{2}$ atmosphere (balloon) overnight at room temperature. Once the reaction was complete, the catalyst was removed by filtration and the dark red filtrate was evaporated under reduced pressure. $\mathrm{CHCl}_{3}(35 \mathrm{~mL})$ was added to the dark violet solid thus obtained and the resulting suspension was stirred for $15 \mathrm{~min}$. Insoluble material was collected by suction, washed with $\mathrm{CHCl}_{3}$ and dried to give hydrochloride $5(0.55 \mathrm{~g}$, $86 \%)$ as a dark violet solid which was used in the next reactions without further purification; $\mathrm{mp}>230{ }^{\circ} \mathrm{C}$ (dec.). ${ }^{1} \mathrm{H}$ NMR (300 MHz, DMSO- $d_{6}$ ) $\delta 7.31$ (d, $1 \mathrm{H}, J=8.8 \mathrm{~Hz}, \mathrm{H}-6$ ), 7.41 (dd, $1 \mathrm{H}, J=8.0,5.0 \mathrm{~Hz}, \mathrm{H}-3), 7.53$ (d, $1 \mathrm{H}, J=8.8 \mathrm{~Hz}, \mathrm{H}-5), 8.48$ $(\mathrm{dd}, 1 \mathrm{H}, J=8.0,1.1 \mathrm{~Hz}, \mathrm{H}-4), 8.75(\mathrm{dd}, 1 \mathrm{H}, J=5.0,1.5 \mathrm{~Hz}$, $\mathrm{H}-2) ;{ }^{13} \mathrm{C}$ NMR (75 MHz, DMSO- $\left.d_{6}\right) \delta 116.7,120.7,121.3$, $122.8,140.3,145.2,164.2$ (not all ${ }^{13} \mathrm{C}$ carbon signals were observed); anal. calcd for $\mathrm{C}_{9} \mathrm{H}_{10} \mathrm{ClN}_{3}$ : C, 55.25; H, 5.15; N, 21.48, found: C, 55.34; H, 5.18; N, 21.55.
7,8-Diaminoquinoline (3). Method $A$ (alkalisation of hydrochloride 5). A solution of hydrochloride 5 (0.24 g, $1.2 \mathrm{mmol})$ in water $(25 \mathrm{~mL})$ was alkalised with a few drops of $20 \% \mathrm{NaOH}$ solution. The resulting solution was filtered under reduced pressure and the filtrate was extracted with ethyl acetate $(4 \times 15 \mathrm{~mL})$. The combined organic phases were dried with $\mathrm{Na}_{2} \mathrm{SO}_{4}$, filtered and evaporated under reduced pressure as rapidly as possible to afford diaminoquinoline $3(0.12 \mathrm{~g}, 61 \%)$ as a dark grey solid which was characterised without further purification; mp 100-102 ${ }^{\circ} \mathrm{C}$ (Ref. [8] mp $102{ }^{\circ} \mathrm{C}$ ). ${ }^{1} \mathrm{H}$ NMR $\left(300 \mathrm{MHz}, \mathrm{DMSO}-d_{6}\right) \delta 5.07$ (br s, $\left.4 \mathrm{H}, 2 \times \mathrm{NH}_{2}\right), 7.02(\mathrm{~d}, J=$ $8.6 \mathrm{~Hz}, 1 \mathrm{H}, \mathrm{H}-6), 7.05$ (d, $J=8.6 \mathrm{~Hz}, 1 \mathrm{H}, \mathrm{H}-5), 7.11$ (dd, $J=$ $8.1,4.2 \mathrm{~Hz}, 1 \mathrm{H}, \mathrm{H}-3$ ), 8.00 (dd, $J=8.1,1.7 \mathrm{~Hz}, 1 \mathrm{H}, \mathrm{H}-4), 8.59$ (dd, $J=4.2,1.7 \mathrm{~Hz}, 1 \mathrm{H}, \mathrm{H}-2) ;{ }^{13} \mathrm{C}$ NMR $\left(75 \mathrm{MHz}\right.$, DMSO- $\left.d_{6}\right)$ $\delta 115.5,116.7,118.7,121.4,126.3,132.6,135.5,137.9,147.3$; anal. calcd for $\mathrm{C}_{9} \mathrm{H}_{9} \mathrm{~N}_{3}: \mathrm{C}, 67.90 ; \mathrm{H}, 5.70 ; \mathrm{N}, 26.40$; found: $\mathrm{C}$, $68.00 ; \mathrm{H}, 5.65 ; \mathrm{N}, 26.47$.

Method B (reduction of 6-chloroselenadiazoloquinoline 2). Powdered $\mathrm{Zn}(0.58 \mathrm{~g}, 8.93 \mathrm{mmol})$ was added to a stirred suspension of 6-chloroselenadiazoloquinoline $2(0.20 \mathrm{~g}$, $0.74 \mathrm{mmol})$ in acetic acid and the mixture was heated under reflux for $4 \mathrm{~h}$. After the reaction was complete, the hot mixture was filtered, the filter cake was washed with acetic acid $(15 \mathrm{~mL})$ and the filtrate was evaporated under reduced pressure. The resulting orange oily residue was dissolved in water $(7 \mathrm{~mL})$ and alkalised with a $10 \% \mathrm{NaOH}$ solution. The yellow suspension was extracted with ethyl acetate $(4 \times 15 \mathrm{~mL})$. The combined organic phases were dried with $\mathrm{Na}_{2} \mathrm{SO}_{4}$, filtered and evaporated under reduced pressure as rapidly as possible to afford diaminoquinoline 3 (37 mg, 31\%) as a dark grey solid which was characterised without further purification; $\mathrm{mp}$ 99-101 ${ }^{\circ} \mathrm{C}$ (Ref. [8] mp $102{ }^{\circ} \mathrm{C}$ ). The ${ }^{1} \mathrm{H}$ and ${ }^{13} \mathrm{C}$ NMR spectral data were in accordance with those of diaminoquinoline 3 prepared by the alkalisation of hydrochloride $\mathbf{5}$.

$[\mathbf{1 , 2 , 5}]$ Selenadiazolo[3,4- $\boldsymbol{h}$ ]quinoline (6). $\mathrm{SeO}_{2}(58.6 \mathrm{mg}$, $0.53 \mathrm{mmol})$ dissolved in water $(1 \mathrm{~mL})$ was added to a stirred solution of hydrochloride $5(100 \mathrm{mg}, 0.51 \mathrm{mmol})$ in water $(1 \mathrm{~mL})$ and stirring was continued for an additional $15 \mathrm{~min}$ at room temperature. Next, the reaction mixture was alkalised with a few drops of $30 \% \mathrm{NaOH}$ solution and the resulting grey precipitate was collected by suction, washed with water $(15 \mathrm{~mL})$ and dried. The mother liquor was extracted with $\mathrm{CHCl}_{3}(1 \times 20 \mathrm{~mL})$, the organic layer was dried with $\mathrm{Na}_{2} \mathrm{SO}_{4}$, filtered and evaporated under reduced pressure. The combined solids obtained after separation by suction and extraction were purified by FLC (silica gel, $\mathrm{CHCl}_{3} / \mathrm{MeOH} 100: 1, R_{\mathrm{f}}=0.31$ ) to give selenadiazoloquinoline $6(92 \mathrm{mg}, 76 \%)$ as brownish needles; mp $153-155^{\circ} \mathrm{C}$ (Ref. [9] mp 150-151 ${ }^{\circ} \mathrm{C}$ ). ${ }^{1} \mathrm{H}$ NMR $\left(300 \mathrm{MHz}, \mathrm{CDCl}_{3}\right) \delta 7.62(\mathrm{dd}, 1 \mathrm{H}, J=8.0,4.4 \mathrm{~Hz}, \mathrm{H}-7), 7.71$ 
(d, 1H, $J=9.5 \mathrm{~Hz}, \mathrm{H}-4), 7.77$ (d, 1H, $J=9.5 \mathrm{~Hz}, \mathrm{H}-5), 8.14$ (dd, $1 \mathrm{H}, J=8.0,1.4 \mathrm{~Hz}, \mathrm{H}-6), 9.04(\mathrm{dd}, 1 \mathrm{H}, J=4.4,1.4 \mathrm{~Hz}$, $\mathrm{H}-8) ;{ }^{13} \mathrm{C} \mathrm{NMR}\left(75 \mathrm{MHz}, \mathrm{CDCl}_{3}\right) \delta 123.1,124.0,128.6,130.6$, 136.0, 144.4, 150.1, 158.5, 160.7; anal. calcd for $\mathrm{C}_{9} \mathrm{H}_{5} \mathrm{~N}_{3} \mathrm{Se}: \mathrm{C}$, 46.17; H, 2.15; N, 17.95, found: C, 46.20; H, 2.14; N, 18.00.

Pyrido[2,3-flquinoxaline (8). Diimine 7 (113 mg, $0.51 \mathrm{mmol}$ ) was added to a stirred solution of hydrochloride 5 (100 mg, $0.51 \mathrm{mmol})$ in $\mathrm{MeOH}(8 \mathrm{~mL})$ and stirring was continued at room temperature for $1.5 \mathrm{~h}$. The volatiles were evaporated under reduced pressure and the residue was purified by FLC (silica gel, $\mathrm{CHCl}_{3} / \mathrm{MeOH} 100: 1, R_{\mathrm{f}}=0.25$ ) to afford pyridoquinoxaline $8(75 \mathrm{mg}, 81 \%)$ as an off-white solid; $\mathrm{mp}$ 147-149 ${ }^{\circ} \mathrm{C}$ (Ref. [16] mp 146.5-147.5 ${ }^{\circ} \mathrm{C}$ ). ${ }^{1} \mathrm{H}$ NMR (300 $\mathrm{MHz}, \mathrm{CDCl}_{3}$ ) $\delta 7.69$ (dd, 1H, $\left.J=8.1,4.3 \mathrm{~Hz}, \mathrm{H}-8\right), 8.03$ (d, 1H, $J=9.1 \mathrm{~Hz}, \mathrm{H}-5), 8.08$ (d, 1H, $J=9.1 \mathrm{~Hz}, \mathrm{H}-6), 8.30$ (dd, 1H, $J$ $=8.1,1.6 \mathrm{~Hz}, \mathrm{H}-7), 9.01(\mathrm{~d}, 1 \mathrm{H}, J=1.9 \mathrm{~Hz}, \mathrm{H}-3), 9.10(\mathrm{~d}, 1 \mathrm{H}, J$ $=1.9 \mathrm{~Hz}, \mathrm{H}-2), 9.21(\mathrm{dd}, 1 \mathrm{H}, J=4.3,1.6 \mathrm{~Hz}, \mathrm{H}-9) ;{ }^{13} \mathrm{C} \mathrm{NMR}$ $\left(75 \mathrm{MHz}, \mathrm{CDCl}_{3}\right) \delta 123.6,128.1,128.4,130.1,136.1,141.3$, 144.4, 144.5, 145.5, 145.7, 150.7; anal. calcd for $\mathrm{C}_{11} \mathrm{H}_{7} \mathrm{~N}_{3}$ : C, 72.92; H, 3.89; N, 23.19; found: C, 72.97; H, 3.90; N, 23.17.

9-Chloro- $[1,2,5]$ selenadiazolo[3,4-f $]$ quinoline (10). A mixture of selenadiazolo[3,4-f]quinolone $9(2.0 \mathrm{~g}, 8.0 \mathrm{mmol})$ and $\mathrm{POCl}_{3}(4 \mathrm{~mL}, 6.56 \mathrm{~g}, 42.8 \mathrm{mmol})$ was stirred at $90{ }^{\circ} \mathrm{C}$ for $3 \mathrm{~h}$. After the reaction was complete, the mixture was cooled to $0{ }^{\circ} \mathrm{C}$ in an ice bath followed by the addition of crushed ice $(\sim 30 \mathrm{~g})$ in one portion under stirring. Once the ice was melted, the resulting brown solution was stirred for $45 \mathrm{~min}$ and subsequently alkalised with a $20 \% \mathrm{NaOH}$ solution under cooling in the ice bath. The grey-brown precipitate was collected by suction, washed with water and dried. Purification by FLC (silica gel, $\mathrm{CHCl}_{3}, R_{\mathrm{f}}=0.21$ ) afforded 9-chloroselenadiazoloquinoline $10(1.90 \mathrm{~g}, 89 \%)$ as a pale yellow solid; mp 225-226 ${ }^{\circ} \mathrm{C} .{ }^{1} \mathrm{H}$ NMR $(300 \mathrm{MHz}, \mathrm{TFA}-d) \delta 8.02(\mathrm{~d}, 1 \mathrm{H}, J=9.7$ $\mathrm{Hz}, \mathrm{H}-4), 8.06$ (d, $1 \mathrm{H}, J=6.3 \mathrm{~Hz}, \mathrm{H}-8), 8.26$ (d, $1 \mathrm{H}, J=9.7 \mathrm{~Hz}$, $\mathrm{H}-5), 8.69$ (d, $1 \mathrm{H}, J=6.1 \mathrm{~Hz}, \mathrm{H}-7) ;{ }^{13} \mathrm{C}$ NMR (75 MHz, TFAd) $\delta 125.2,126.1,129.9,134.5,143.3,145.8,155.2,158.6$, 159.7; anal. calcd for $\mathrm{C}_{9} \mathrm{H}_{4} \mathrm{ClN}_{3} \mathrm{Se}$ : C, 40.25; H, 1.50; N, 15.65; found: C, 40.21; H, 1.51; N, 15.67 .

4-Chloro-5,6-diaminoquinoline (11). 9-Chloroselenadiazoloquinoline $10(0.50 \mathrm{~g}, 1.86 \mathrm{mmol})$ was added in small portions to a stirred suspension of $\mathrm{SnCl}_{2} \cdot 2 \mathrm{H}_{2} \mathrm{O}(1.68 \mathrm{~g}, 7.44 \mathrm{mmol})$ in concentrated $\mathrm{HCl}(15 \mathrm{~mL})$ at room temperature and stirring was continued for $30 \mathrm{~min}$. Next, the reaction mixture was diluted with water $(40 \mathrm{~mL})$, the insoluble material was removed by filtration under reduced pressure and the filter cake was washed with water $(20 \mathrm{~mL})$. The filtrate was subsequently alkalised with saturated $\mathrm{Na}_{2} \mathrm{CO}_{3}$ solution and the resulting yellow suspension was extracted with ethyl acetate $(6 \times 75 \mathrm{~mL})$. In the first extraction, precipitation of the product occurred between the organic and water phases due to its low solubility in ethyl acetate. In this case, the water phase was separated to leave the precipitate in the organic phase in a separatory funnel. Methanol $(15 \mathrm{~mL})$ was added to this suspension to dissolve the precipitated product and the resulting yellow solution was put aside. The water phase was extracted with 5 additional portions of ethyl acetate. The combined organic phases were dried with $\mathrm{Na}_{2} \mathrm{SO}_{4}$, filtered and evaporated under reduced pressure to afford 4-chlorodiaminoquinoline $11(0.28 \mathrm{~g}, 77 \%)$ as a yellow-brown solid which was characterised without further purification; $\mathrm{mp}>150{ }^{\circ} \mathrm{C}$ (dec.). ${ }^{1} \mathrm{H}$ NMR $(300 \mathrm{MHz}$, DMSO$\left.d_{6}\right) \delta 5.13$ (br s, $2 \mathrm{H}, \mathrm{NH}_{2}$ ), 5.23 (br s, $2 \mathrm{H}, \mathrm{NH}_{2}$ ), 7.27 (s, $2 \mathrm{H}$, H-7, H-8), 7.28 (d, 1H, $J=4.5 \mathrm{~Hz}, \mathrm{H}-3), 8.29$ (d, 1H, $J=4.5$ $\mathrm{Hz}, \mathrm{H}-2) ;{ }^{13} \mathrm{C}$ NMR $\left(75 \mathrm{MHz}, \mathrm{DMSO}-d_{6}\right) \delta 114.8,118.9$, $121.5,121.6,125.8,132.8,136.8,144.52,144.53$; anal. calcd for $\mathrm{C}_{9} \mathrm{H}_{8} \mathrm{ClN}_{3}$ : C, 55.83; H, 4.16; N, 21.70, found: C, 55.93; H, $4.12 ; \mathrm{N}, 21.79$.

\section{Supporting Information}

\section{Supporting Information File 1}

${ }^{1} \mathrm{H}$ and ${ }^{13} \mathrm{C}$ NMR spectra of compounds 2-6, 8, 10 and 11. [http://www.beilstein-journals.org/bjoc/content/ supplementary/1860-5397-9-302-S1.pdf]

\section{Acknowledgements}

The authors wish to express their gratitude to the Scientific Grant Agency (VEGA project 1/0660/11) and to the Slovak Research and Development Agency (contracts nos. APVV0339-10 and APVV-0038-11) for the financial support received.

\section{References}

1. Aleksandrov, A. A.; Dedeneva, A. S.; Vlasova, E. V.; El'chaninov, M. M. Russ. J. Org. Chem. 2011, 47, 120-123.

doi:10.1134/S1070428011010155

2. Lee, J. H.; Ahn, M. H.; Choi, E. H.; Choo, H.-Y. P.; Han, G. Heterocycles 2006, 70, 571-580. doi:10.3987/COM-06-S(W)25

3. Rajitha, B.; Rao, M. K.; Reddy, P. N. Indian J. Chem., Sect. B 2004, 43, 417-419.

4. Ziv, J.; Knapp, S.; Rosen, J. D. Synth. Commun. 1988, 18, 973-980. doi:10.1080/00397918808060881

5. Renshaw, R. R.; Friedman, H. L.; Gajewski, F. J. J. Am. Chem. Soc. 1939, 61, 3322-3326. doi:10.1021/ja01267a026

6. Hudson, A. Skraup/Doebner-von Miller reaction. In Name Reactions in Heterocyclic Chemistry; Li, J. J., Ed.; Wiley \& Sons: Hoboken, NJ, 2005; pp 488-494.

7. Linsker, F.; Evans, R. L. J. Am. Chem. Soc. 1946, 68, 149-150. doi:10.1021/ja01205a513

8. Colonna, M.; Montanari, F. Gazz. Chim. Ital. 1951, 81, 744-756.

9. Sharma, K. S.; Kumari, S.; Singh, R. P. Synthesis 1981, 316-318. doi:10.1055/s-1981-29435 
10. Moores, I. G.; Smalley, R. K.; Suschitzky, H. J. Fluorine Chem. 1982, 20, 573-580. doi:10.1016/S0022-1139(00)82282-4

11. Huisgen, R. Justus Liebigs Ann. Chem. 1948, 559, 101-152. doi:10.1002/jlac.19485590204

12. Sharma, K. S.; Kumari, S.; Singh, R. P. Indian J. Chem., Sect. B 1981, 20, 744-746

13. Bella, M.; Schultz, M.; Milata, V.; Koňariková, K.; Breza, M. Tetrahedron 2010, 66, 8169-8174. doi:10.1016/j.tet.2010.08.044

14. Bella, M.; Schultz, M.; Milata, V. ARKIVOC 2012, No. iv, 242-251. doi:10.3998/ark.5550190.0013.418

15. Milata, V.; Ilavský, D.; Leško, J. Collect. Czech. Chem. Commun. 1988, 53, 1068-1077. doi:10.1135/cccc19881068

16. Case, F. H.; Brennan, J. A. J. Am. Chem. Soc. 1959, 81, 6297-6301. doi:10.1021/ja01532a046

17. Linsker, F.; Evans, R. L. J. Am. Chem. Soc. 1946, 68, 874-876. doi:10.1021/ja01209a051

18. Carson, J. F. J. Am. Chem. Soc. 1953, 75, 4337-4338. doi:10.1021/ja01113a507

19. Grivas, S.; Tian, W.; Ronne, E.; Lindström, S.; Olsson, K. Acta Chem. Scand. 1993, 47, 521-528. doi:10.3891/acta.chem.scand.47-0521

\section{License and Terms}

This is an Open Access article under the terms of the Creative Commons Attribution License

(http://creativecommons.org/licenses/by/2.0), which permits unrestricted use, distribution, and reproduction in any medium, provided the original work is properly cited.

The license is subject to the Beilstein Journal of Organic Chemistry terms and conditions:

(http://www.beilstein-journals.org/bjoc)

The definitive version of this article is the electronic one which can be found at: doi:10.3762/bjoc. 9.302 